\title{
Presence of Acidic Aerosol
}

4

5 Matthieu Riva ${ }^{a}$, Sri Hapsari Budisulistiorini ${ }^{a}, Z_{\text {Zhenfa Zhang }}^{a}$, Avram Gold $^{a}$ and Jason D.

6 Surratt $^{a^{*}}$

7

${ }^{a}$ Department of Environmental Sciences and Engineering, Gillings School of Global Public

9 Health, The University of North Carolina at Chapel Hill, Chapel Hill, NC, United States

10

11

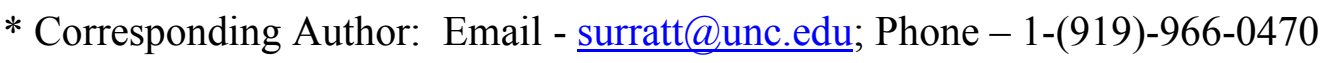

\section{HIGHLIGHTS}

- Acidified sulfate aerosol enhances production of SOA from isoprene ozonolysis.

- Isoprene ozonolysis in the presence of acidic aerosol yields 2-methyltetrols.

- Unique organosulfates (OSs) are characterized from isoprene ozonolysis.

- 2-Methyltetrols and OSs may originate from heterogeneous reaction of peroxides.

\section{KEYWORDS}




\section{ABSTRACT}

23 Isoprene is the most abundant non-methane hydrocarbon emitted into Earth's atmosphere and

24 is predominantly derived from terrestrial vegetation. Prior studies have focused largely on the hydroxyl $(\mathrm{OH})$ radical-initiated oxidation of isoprene and have demonstrated that highly oxidized compounds, such as isoprene-derived epoxides, enhance the formation of secondary organic aerosol (SOA) through heterogeneous (multiphase) reactions on acidified sulfate aerosol. However, studies on the impact of acidified sulfate aerosol on SOA formation from isoprene ozonolysis are lacking and the current work systematically examines this reaction. SOA was generated in an indoor smog chamber from isoprene ozonolysis under dark conditions in the presence of non-acidified or acidified sulfate seed aerosol. The effect of $\mathrm{OH}$ radicals on SOA chemical composition was investigated using diethyl ether as an $\mathrm{OH}$ radical scavenger. Aerosols were collected and chemically characterized by ultra performance liquid chromatography/electrospray ionization high-resolution quadrupole time-of-flight mass spectrometry (UPLC/ESI-HR-QTOFMS) and gas chromatography/electron impact ionizationmass spectrometry (GC/EI-MS). Analysis revealed the formation of highly oxidized compounds, including organosulfates (OSs) and 2-methylterols, which were significantly enhanced in the presence of acidified sulfate seed aerosol. OSs identified in the chamber experiments were also observed and quantified in summertime fine aerosol collected from two rural locations in the southeastern United States during the 2013 Southern Oxidant and Aerosol Study (SOAS). 


\section{INTRODUCTION}

The largest mass fraction of fine particulate matter $\left(\mathrm{PM}_{2.5}\right.$, aerosol with aerodynamic diameters $\leq 2.5 \mu \mathrm{m}$ ) is generally organic, dominated by secondary organic aerosol (SOA) formed from the gas-phase oxidation of volatile organic compounds (VOCs). Although SOA contributes a large portion (20-90\%) of the total $\mathrm{PM}_{2.5}$ mass, for the most part current models under-predict SOA mass (Kroll and Seinfeld, 2008; Hallquist et al., 2009). Biogenic VOCs (BVOCs), such as isoprene and monoterpenes, are typically the most abundant SOA precursors, especially in regions of dense terrestrial vegetation (Guenther et al., 2006).

Isoprene (2-methyl-1,3-butadiene, $\mathrm{C}_{5} \mathrm{H}_{8}$ ) is the most abundant non-methane hydrocarbon emitted into the troposphere with emissions exceeding $500 \mathrm{Tg}^{-1}{ }^{-1}$ (Guenther et al., 2006). The principal atmospheric degradation pathway of isoprene is oxidation by hydroxyl $(\mathrm{OH})$ radical (Atkinson, 1997; Edney et al., 2005; Kroll et al., 2006), which along with oxidation by nitrate $\left(\mathrm{NO}_{3}\right)$ radical and ozone $\left(\mathrm{O}_{3}\right)$, accounts for up to $50 \%$ of the SOA budget $($ Henze and Seinfeld, 2006). Before 2004, SOA formation from atmospheric oxidation of isoprene was considered insignificant (Kamens et al., 1982; Pandis et al., 1991) because of the low molecular weight and high volatility of its known oxidation products and as a consequence, isoprene was not included in SOA models. However, the identification by Claeys and coworkers of 2-methyltetrols (Claeys et al., 2004a) and $\mathrm{C}_{5}$-alkene triols (Wang et al., 2005) in ambient $\mathrm{PM}_{2.5}$ collected in the Amazon caused a re-examination of the potential for isoprene oxidation to yield SOA. Since the 2-methyltetrols and $\mathrm{C}_{5}$-alkene triols contain the isoprene skeleton, isoprene was proposed as their source, although the mechanisms and environmental conditions leading to these products as well as the formation of isoprene SOA were not evident. Research over the last decade has established that relative humidity (RH) (Nguyen et al., 2011), levels of nitrogen oxides $\left(\mathrm{NO}_{\mathrm{x}}\right)$ (Kroll et al., 2006; Chan et al., 2010) and aerosol acidity (Surratt et al., 2007a, b) have pronounced effects on isoprene SOA formation. Recent 
studies show that increased aerosol acidity is a key variable in enhancing SOA formation through the acid-catalyzed reactive uptake and multiphase chemistry of the $\mathrm{OH}$ radicalinitiated oxidation products of isoprene, particularly the isomeric isoprene epoxydiols (IEPOX) (Paulot et al., 2009; Surratt et al., 2010; Lin et al., 2012; Gaston et al., 2014). Acidcatalyzed particle-phase reactions of IEPOX have been shown to yield the 2-methyltetrols and $\mathrm{C}_{5}$-alkene triols as well as IEPOX-derived dimers observed in the Amazonian $\mathrm{PM}_{2.5}$ (Surratt et al., 2010; Lin et al., 2012). Epoxides generated by $\mathrm{OH}$ radical oxidation of isoprene have also been shown to explain the formation known organosulfates (OSs) and oligomers measured in ambient $\mathrm{PM}_{2.5}$ samples (Surratt et al., 2007a, 2008; Lin et al., 2014). Although research over the last decade has focused principally on $\mathrm{OH}$ radical-initiated oxidation of isoprene, some work has also demonstrated significant $\mathrm{SOA}$ formation from the $\mathrm{NO}_{3}$ radicalinitiated oxidation of isoprene ( $\mathrm{Ng}$ et al., 2008).

The contribution of isoprene ozonolysis to the SOA budget had been concluded to be negligible (Hasson et al., 2001; Kleindienst et al. 2007; Sato et al., 2013) on the basis of a large number of studies reporting only volatile and semivolatile products, such as methyl vinyl ketone (MVK), methacrolein (MACR) or low molecular weight acids. However, the potential importance of isoprene ozonolysis as a pathway for SOA formation is supported by recent studies documenting the formation of highly oxidized products, including oligomers, in both gas and particulate phases (Nguyen et al., 2010; Inomata et al., 2014). Initial formation of isoprene primary ozonides leads to stabilized Criegee intermediates (sCIs), which can react to form $\mathrm{OH}$ radicals, undergo further oxidation or condense to form higher molecular weight products. The total yield of sCIs, including $\mathrm{CH}_{2} \mathrm{OO}$ radical and higher molecular weight fragments, was determined to be 0.26 (Hasson et al., 2001), and the yield of $\mathrm{OH}$ radicals to be $0.25-0.27$ (Atkinson et al., 1992). Formation of highly oxidized compounds, such as oligomeric hydroperoxides identified in recent studies (Nguyen et al., 2010; Inomata et al., 
2014), was proposed by the reaction of sCIs with organic ozonolysis products (e.g. carboxylic acids) of isoprene. Multiphase reactions of the oxidized products could thus make significant contributions to the yield of SOA from isoprene ozonolysis. With the exception of reports by Jang et al. (2002) and Czoschke et al. (2003), effects of varying composition and acidity of sulfate aerosols and the presence of $\mathrm{OH}$ scavengers on SOA generated from isoprene ozonolysis have not been systematically investigated, nor have efforts have been reported to identify products unique to isoprene ozonolysis in ambient $\mathrm{PM}_{2.5}$ samples collected from isoprene-rich areas.

In this study we investigate isoprene ozonolysis in the presence of sulfate seed aerosol of varying acidity and composition with a focus on the formation of OSs and highly oxidized compounds. Because of the high yield of $\mathrm{OH}$ radicals from isoprene ozonolysis, experiments were performed both in the presence and absence of an $\mathrm{OH}$ radical scavenger in order to identify SOA constituents derived directly from ozonolysis. Filters collected from indoor smog chamber experiments were analyzed by ultra performance liquid chromatography/ electrospray ionization high-resolution quadrupole time-of-flight mass spectrometry (UPLC/ESI-HR-QTOFMS) and gas chromatography/electron impact mass spectrometry (GC/EI-MS). $\mathrm{PM}_{2.5}$ samples collected from ground sites at Look Rock, TN, and Centerville, AL, during the 2013 Southern Oxidant and Aerosol Study (SOAS) were also analyzed to identify OSs present in both field and chamber studies and quantify their contribution to ambient $\mathrm{PM}_{2.5}$. Comparison of lab and field data supports the potential importance of isoprene ozonolysis in the isoprene-derived SOA budget.

\section{EXPERIMENTAL SECTION}

2.1 Smog Chamber Experiments. Ten experiments were performed in the indoor environmental smog chamber at the University of North Carolina. The experimental setup and 
analysis techniques used in this work were described in detail previously (Lin et al., 2012;

120 Zhang et al., 2012). Briefly, experiments were carried out under dark and dry conditions (3.3

$121 \pm 0.25 \%, \mathrm{RH})$ at $296 \pm 1 \mathrm{~K}$ in a $10-\mathrm{m}^{3}$ Teflon chamber. Experimental conditions are

122 summarized in Table 1. Prior to each experiment, the chamber was flushed continuously with

123 clean air for $\sim 24$ hours until the particle mass concentration was $<0.01 \mu \mathrm{g} \mathrm{m}^{-3}$ to ensure that

124 there were no pre-existing aerosol particles prior to injection of isoprene. Aerosol size

125 distributions were continuously measured using a differential mobility analyzer (DMA, BMI

126 model 2002) coupled to a mixing condensation particle counter (MCPC, BMI model 1710) in

127 order to monitor aerosol number, surface area, and volume concentration within the chamber.

128 Chamber flushing also reduced $\mathrm{O}_{3}$ and VOC concentrations below the detection limit $(<1$

$129 \mathrm{ppb}$ for ozone and isoprene). Temperature and $\mathrm{RH}$ in the chamber were continuously

130 monitored using a dew point meter (Omega Engineering Inc.).

131 A known quantity of isoprene (Sigma-Aldrich, 99\%) was introduced into the chamber

132 by passing a heated nitrogen $\left(\mathrm{N}_{2}\right)$ stream through a heated glass manifold. In some

133 experiments, diethyl ether was injected by the same procedure to serve as an $\mathrm{OH}$ scavenger.

134 Concentrations of isoprene and diethyl ether were measured every 10 minutes using an online

135 gas chromatography/flame ionization detector (GC-FID, Model CP-3800, Varian), which was

136 calibrated using multiple injections of isoprene and diethyl ether. Approximately $100 \mathrm{ppb}$ of

137 isoprene was injected for each experiment, while $3.5 \mathrm{ppm}$ of diethyl ether was introduced in

138 the experiments performed in the presence of $\mathrm{OH}$ scavenger. Approximately 1 hour after

139 isoprene injection, $120-150 \mathrm{ppb}$ of $\mathrm{O}_{3}$ was introduced into the chamber using an $\mathrm{O}_{3}$ generator

140 (Model L21, Pacific ozone). $\mathrm{O}_{3}$ concentration was monitored over the course of experiments 141 using an UV photometric analyzer (Model 49P, Thermo-Environmental).

142 Non-acidified or acidified ammonium or magnesium sulfate seed aerosols were 143 introduced two hours after $\mathrm{O}_{3}$ injection. Non-acidified seed aerosol was generated from 0.06 
$144 \mathrm{M}$ magnesium sulfate $\left(\mathrm{MgSO}_{4}\right)$ or ammonium sulfate $\left(\left(\mathrm{NH}_{4}\right)_{2} \mathrm{SO}_{4}\right)$ (aq) solutions and

145 acidified seed aerosol from $0.06 \mathrm{M} \mathrm{MgSO}_{4}(\mathrm{aq})$ or $\left(\mathrm{NH}_{4}\right)_{2} \mathrm{SO}_{4}(\mathrm{aq})+0.06 \mathrm{M} \mathrm{H}_{2} \mathrm{SO}_{4}(\mathrm{aq})$

146 solutions. Once aerosol volume concentrations stabilized ( $\sim 1$ hour after reaction), aerosols

147 were collected onto 47-mm diameter Teflon filters (1.0- $\mu \mathrm{m}$ pore size, Tisch Environmental,

148 EPA $\mathrm{PM}_{2.5}$ membrane) for two hours at a sampling flow rate of $25 \mathrm{~L} \mathrm{~min}^{-1}$ to characterize 149 particle-phase reaction products.

$150 \quad 2.2$ Ambient PM$_{2.5}$ Collection. PM $_{2.5}$ samples were collected during the 2013 SOAS 151 campaign from 1 June to 15 July 2013 at Centerville, AL (CTR), and from 1 June to 17 July 1522013 at Look Rock, TN (LRK). Both sites are strongly influenced by isoprene emissions 153 (Guenther et al., 2006), and isoprene oxidation appears to be one of the main SOA 154 contributors (Budisulistiorini et al., 2015; $\mathrm{Xu}$ et al., 2015). At each site, $\mathrm{PM}_{2.5}$ samples were 155 collected onto pre-baked $8 \times 10$ in Tissuquartz ${ }^{\mathrm{TM}}$ Filters (Pall Life Sciences) with high156 volume $\mathrm{PM}_{2.5}$ air samplers (Tisch Environmental) operated at $1 \mathrm{~m}^{3} \mathrm{~min}^{-1}$ using two sampling 157 protocols described in detail elsewhere (Budisulistiorini et al. 2015). A total of 118 filters 158 from CTR and 123 filters from LRK were analyzed to evaluate the contributions of OSs 159 identified from isoprene ozonolysis on the isoprene-derived SOA budget. from isoprene ozonolysis was performed by UPLC/ESI-HR-Q-TOFMS (6520 Series, Agilent) operated in the negative ion mode and by GC/EI-MS (Hewlett-Packard, 5890 Series II). 163 Operating conditions have been described in detail in elsewhere (Lin et al., 2012). Filters 164 collected from smog chamber experiments were extracted with $22 \mathrm{~mL}$ of high-purity 165 methanol (LC-MS CHROMASOLV-grade, Sigma-Aldrich) by sonication for 45 min. The 166 methanol extracts were blown dry under a gentle $\mathrm{N}_{2}(\mathrm{~g})$ stream at ambient temperature. Dried 167 extracts were reconstituted in $2 \mathrm{~mL}$ methanol, divided into two equal portions and then blown 168 dry. 
For UPLC/ESI-HR-QTOFMS analysis, one of the dried extracts was reconstituted with $150 \mu \mathrm{L}$ of a 50:50 (v/v) solvent mixture of methanol (LC-MS CHROMASOLV-grade,

171 Sigma-Aldrich) and high-purity water (Milli-Q, 18.2 M $\Omega$ ). $5 \mu$ L aliquots were injected onto 172 the UPLC column (Waters ACQUITY UPLC HSS T3 column, $2.1 \times 100 \mathrm{~mm}, 1.8 \mu \mathrm{m}$ particle 173 size) and eluted at a flow rate of $0.3 \mathrm{~mL} \mathrm{~min}^{-1}$ with a solvent mixture of methanol containing $1740.1 \%$ acetic acid (LC-MS CHROMASOLV-grade, Sigma-Aldrich) and water containing 0.1 $175 \%$ acetic acid (LC-MS CHROMASOLV-grade, Sigma-Aldrich). OSs were characterized by 176 high-resolution mass spectra to determine the composition of SOA constituents and structural 177 information was obtained through acquisition of high-resolution tandem mass spectra $\left(\mathrm{MS}^{2}\right)$ 178 at a collision energy of $15 \mathrm{~V}$. A mixture of 2-methyltetrol sulfate esters $\left(\mathrm{C}_{5} \mathrm{H}_{11} \mathrm{O}_{7} \mathrm{~S}^{-}\right)$ 179 (Budisulistiorini et al., 2015) and 2-oxopropyl sulfate (hydroxyacetone sulfate ester; 180 $\mathrm{C}_{3} \mathrm{H}_{5} \mathrm{O}_{5} \mathrm{~S}^{-}$; SI Figures $\mathrm{S} 1$, S2) were synthesized in-house as authentic standards. Propyl sulfate $\left(\mathrm{C}_{3} \mathrm{H}_{7} \mathrm{O}_{4} \mathrm{~S}^{-}\right.$; electronic grade, City Chemical LLC) and 3-pinanol-2-hydrogen sulfate $\left(\mathrm{C}_{9} \mathrm{H}_{13} \mathrm{O}_{6} \mathrm{~S}^{-}\right.$; synthesized standard from Marianne Glasius's group) served as surrogate 183 standards to quantify the remaining OSs. The second portion of dried filter extract was trimethylsilylated by addition of $100 \mu \mathrm{L}$ BSTFA + trimethylchlorosilane (99:1 (v/v), Supleco) and $50 \mu \mathrm{L}$ pyridine (Sigma-Aldrich, $98 \%$, anhydrous). The mixture was heated for $1 \mathrm{~h}$ at $70{ }^{\circ} \mathrm{C}$ and analyzed within 24 hours 187 following trimethylsilylation. Analyses were performed by GC/EI-MS at $70 \mathrm{eV}$ (Hewlett 1885890 Packard Series II Gas Chromatograph interfaced to a HP 5971A Series Mass Selective 189 Detector, Econo-CapTM-ECTM-5 column, $30 \mathrm{~m} \times 0.25 \mathrm{~mm} \times 0.25 \mu \mathrm{m})$. 2-Methyltetrols were quantified using the authentic standard (Budisulistiorini et al., 2015).

Filters collected from field studies were extracted using the protocol described above;

192 however, prior to drying, extracts were filtered through $0.2-\mu \mathrm{m}$ PTFE syringe filters (Pall Life 193 Science, Acrodisc) to remove insoluble particles or quartz filter fibers. 


\section{RESULTS AND DISCUSSION}

195

3.1 OS formation. In addition to four sulfate esters previously reported from photooxidation of isoprene under low- or high- $\mathrm{NO}_{\mathrm{x}}$ conditions (Surratt et al., 2008) (Table 1), 12 products unique to ozonolysis were identified and quantified (Table 2).

Negative ion UPLC/ESI-HR-QTOFMS analysis of filter extracts provides excellent sensitivity for the detection of OSs, which yield intense $[\mathrm{M}-\mathrm{H}]^{-}$ions (Surratt et al., 2008; Hansen et al., 2014) and show characteristic product ions at $m / z 80\left(\mathrm{SO}_{3}{ }^{\circ /}\right), 81\left(\mathrm{HSO}_{3}{ }^{-}\right)$or 97 $\left(\mathrm{HSO}_{4}{ }^{-}\right)$in $\mathrm{MS}^{2}$ spectra. Accurate mass measurements of parent and major product ions, number of isomers/isobars for each parent mass, $\mathrm{MS}^{2}$ spectra and proposed structures are given in Figure 1 and Supporting Information (SI; Figures S3 and S4 and Table S1). 2Methyltetrol sulfate esters (isomers not specified) and 2-oxopropyl sulfate were identified by comparison with the authentic standards; other structures have been tentatively assigned based on accurate mass measurements of parent and product ions and comparison of $\mathrm{MS}^{2}$ fragmentation patterns with those of structurally similar OSs available in the literature such as the OSs at $m / z$ 169, 213, and 215 (Surratt et al., 2007a; Gomez-Gonzalez et al., 2008), the OS at $m / z 199$ (Zhang et al., 2012), and the OS at $m / z 183$ (Safi Shalamzari et al., 2013). Figures 1a-f illustrate the assignment of structures for the major OSs identified in both laboratorygenerated and ambient SOA.

Two isobaric parent ions with the composition $\mathrm{C}_{4} \mathrm{H}_{7} \mathrm{O}_{6} \mathrm{~S}^{-}(\mathrm{m} / z$ 183) in Figure $1 \mathrm{a}$ and $\mathrm{b}$ lose bisulfate $(\mathrm{m} / \mathrm{z} 97)$ as the base peak fragment ion and can thus be identified as OSs with a labile proton $\beta$ to the sulfate group; proposed fragmentation schemes for these two isomers can be found in Figures S3a and S3b. An OS with this composition has been reported in ambient $\mathrm{PM}_{2.5}$ (Safi Shalamzari et al., 2013), and was assigned as the $O^{3}$-sulfate ester of 3,4dihydroxybutan-2-one based by comparison of its $\mathrm{MS}^{2}$ spectrum with the $\mathrm{MS}^{2}$ spectrum of a synthetic mixture of the $O^{3}-+O^{4}$-sulfate esters of 3,4-dihydroxybutan-2-one. While these 
data were acquired on an Orbitrap mass spectrometer and a QTOFMS was employed in this

220 study, the key product ions at $m / z 165\left[\mathrm{M}-\mathrm{H}_{2} \mathrm{O}\right], 153\left[\mathrm{M}-\mathrm{CH}_{2} \mathrm{O}\right]$ and $97\left[\mathrm{HSO}_{4}^{-}\right]$are

221 common to both analyses and in accord with monosulfated 3,4-diol isomers of of 3,4-

222 dihydroxybutan-2-one. In Figure 1b, an additional product ion appears in the $\mathrm{MS}^{2}$ spectrum of

223 the late-eluting peak at $m / z 85\left[\mathrm{M}-\mathrm{H}_{2} \mathrm{SO}_{4}\right]$. Loss of $\mathrm{H}_{2} \mathrm{SO}_{4}$ as a neutral fragment to give 3-

224 oxobut-1-en-1-olate, a homolog of the known, stable enolate of malondialdehyde, would be

225 favored by the $O^{3}$-sulfate ester (Figure S3b). In addition, the loss of formaldehyde to give the

226 product ion at $\mathrm{m} / \mathrm{z} 153$ is also favored. The favorability of both fragmentation pathways by the

$227 O^{3}$-ester might be expected to result in reduced parent ion intensity relative to the $O^{4}$-ester at a

228 given collisional energy, as is observed in the $\mathrm{MS}^{2}$ spectrum (Figure 1b). On this basis $O^{3}$ -

229 and $\mathrm{O}^{4}$-sulfate ester structural assignments have been made for the late- and early-eluting

230 products, respectively.

231 Regarding a possible source of the $m / z 183$ isomers, the epoxide of MVK (1-oxiran-2-yl-

232 ethan-1-one) has been proposed as the precursor (Safi Shalamzari et al. 2013). The oxirane is

233 unlikely to be a product of gas-phase ozonolysis of MVK (Neeb et al., 1998). However,

234 uptake onto sulfate aerosols of gas-phase organic peroxides from the reaction of sCIs with

235 carboxylic acids (Nguyen et al., 2010; Inomata et al., 2014) is a potential source of aerosol

236 phase oxidants either by oxidation of sulfate to $\mathrm{SO}_{4}{ }^{-/ \bullet}$ or via generation of $\mathrm{H}_{2} \mathrm{O}_{2}$ (Chen et al.,

237 2008). An $m / z 183$ product has been identified from sulfate radical oxidation of MVK in bulk

238 aqueous solution (Schindelka et al., 2013), suggesting aerosol-phase oxidation by $\mathrm{SO}_{4}^{-{ }^{-\bullet}}$ is

239 possible. Hence, aerosol-phase oxidation by $\mathrm{SO}_{4}{ }^{-/ \bullet}$ or acid-catalyzed ring opening of

240 peroxide-generated oxiranes (Iinuma et al., 2009; Surratt et al., 2010) are plausible routes to

$241 \mathrm{~m} / \mathrm{z} 183$ and other OSs. Sulfate addition to alkenes or aldehyde groups under strong acid

242 conditions (Liggio et al., 2006; Surratt et al., 2007a) could also be considered as an alternative

243 pathway to some products. 
Two ions were identified at $\mathrm{m} / z 197\left(\mathrm{C}_{5} \mathrm{H}_{9} \mathrm{O}_{6} \mathrm{~S}^{-}\right)$. OSs with this nominal mass have been

245 tentatively identified as sulfate esters of $\mathrm{C}_{5}$-alkene triols from uptake of isoprene oxidation

246 products onto acidified sulfate aerosol (Surratt et al., 2007a). However, molecular

247 compositions were not verified by accurate mass measurements and $\mathrm{MS}^{2}$ spectra were not 248 reported. $\mathrm{MS}^{2}$ spectra of products at $\mathrm{m} / \mathrm{z} 197$ observed in our ozonolysis experiment (Figures

249 1c, d; Figures S3c, d) are consistent with a tentative assignment as isomeric sulfate esters of 250 the alkene triol 1,4-dihydroxy-3-methylbutan-2-one. The early eluting sulfate is assigned the 251 structure 4-hydroxy-2-methyl-3-oxobutyl sulfate based on the loss of the neutral fragment $252 \mathrm{C}_{2} \mathrm{H}_{4} \mathrm{O}_{2}$ (2-hydroxyacetaldehyde) to give a product ion at $m / z 137\left(\mathrm{C}_{3} \mathrm{H}_{5} \mathrm{O}_{4} \mathrm{~S}^{-}\right)$(Figure S3c), 253 and the late-eluting isomer is assigned as the 2-oxo sulfate based on the loss of 60 mass units $254\left(\mathrm{C}_{3} \mathrm{H}_{8} \mathrm{O}\right)$ to give a product ion at $\mathrm{m} / z 139\left(\mathrm{C}_{2} \mathrm{H}_{3} \mathrm{O}_{5} \mathrm{~S}^{-}\right)$(Figure $\mathrm{S} 3 \mathrm{~d}$ ). Prominent ions are 255 present for bisulfate $\left(\mathrm{m} / z\right.$ 97), $\mathrm{SO}_{3}{ }^{-/ \bullet}\left(\mathrm{m} / \mathrm{z}\right.$ 80) and loss of formaldehyde $\left(\mathrm{m} / \mathrm{z}\right.$ 167) in $\mathrm{MS}^{2}$ 256 spectra of both early- and late-eluting isomers, consistent with the proposed OS structures.

257 An ion at $m / z 199$ with composition $\mathrm{C}_{5} \mathrm{H}_{11} \mathrm{O}_{7} \mathrm{~S}^{-}$(Figure 1e) has been observed as a 258 component of SOA generated by the reactive uptake of oxidation products of 2-methyl-3259 buten-2-ol (MBO) on both acidified and neutral ammonium sulfate aerosols (Zhang et al., 260 2012) and tentatively identified as 2,3-dihydroxy-3-methylbutyl sulfate. Bisulfate is the only 261 significant product ion in the $\mathrm{MS}^{2}$, which is identical to the $\mathrm{MS}^{2}$ spectrum obtained from the 262 ozonolysis experiment in this study (Figure 1e). Since terminal hydroxymethylene groups in 263 possible isobaric structures would be expected to result in $\mathrm{MS}^{2}$ pathways yielding more 264 complex fragmentation patterns, the structural assignment 2,3-dihydroxy-3-methylbutyl 265 sulfate is tentatively made for this ozonolysis product. The parent ion at $m / z 215\left(\mathrm{C}_{5} \mathrm{H}_{11} \mathrm{O}_{7} \mathrm{~S}^{-}\right)$ 266 has been identified as a 2-methyltetrol sulfate isomer (or isomer mixture) by comparison of 267 the retention time and $\mathrm{MS}^{2}$ spectrum with the authentic standard mixture. Its $\mathrm{MS}^{2}$ spectrum is 268 characterized by loss of bisulfate as the only significant fragmentation (Figures 1f, S3f). 
All the parent ions of products in Tables 1 and 2 show an intense product ion at $\mathrm{m} / \mathrm{z} 97$, characteristic of sulfate esters with a labile proton in proximity to the sulfate group. Two ions 271 are present at $\mathrm{m} / z 153$ with composition $\mathrm{C}_{3} \mathrm{H}_{5} \mathrm{O}_{5} \mathrm{~S}^{-} . \mathrm{MS}^{2}$ spectra of earlier- and later-eluting 272 products are presented in Figures S4a and S4b, respectively. Products with this composition, 273 tentatively identified as the sulfate ester of hydroxyacetone (2-oxopropyl sulfate), a known 274 oxidation product of isoprene, have been observed in SOA from uptake of isoprene oxidation 275 products onto acidic sulfate seed aerosol (Surratt et al., 2007a) and from bisulfate radical oxidation of isoprene in bulk solution (Schindelka et al., 2013). The later-eluting product was

277 identified as 2-oxopropyl sulfate by matching retention time and $\mathrm{MS}^{2}$ with an authentic 278 sample. The $\mathrm{MS}^{2}$ of the earlier-eluting product was identical (Figures S4a1, 4a2), yielding 279 product ions for loss of bisulfate, bisulfite and $\mathrm{SO}_{3}$ and therefore not informative regarding 280 structural identification. The tautomer of 2-oxopropyl sulfate, 1-oxopropan-2-yl sulfate, is a 281 possible isobaric structure.

282 Only one of two ions at $m / z 169\left(\mathrm{C}_{3} \mathrm{H}_{5} \mathrm{O}_{6} \mathrm{~S}^{-}\right)$was present in sufficient abundance for 283 acquisition of an $\mathrm{MS}^{2}$ spectrum. The $\mathrm{MS}^{2}$ is not consistent with the $\mathrm{MS}^{2}$ reported for an 284 authentic sample of the known lactic acid sulfate (Olson et al., 2011; Safi Shalamzari et al., 285 2013). Although the published spectrum was acquired on an instrument equipped with an ion 286 trap source and complete correspondence to QTOFMS in this study might not be assumed, the 287 product ions in the $\mathrm{MS}^{2}$ spectra in this study (Figure S4b) are incompatible with the lactic 288 acid derivative. A potential candidate for $m / z 169$ isomers observed here are the sulfate esters 289 of glyceraldehyde (2,3-dihydroxypropanal), which is a known product from isoprene 290 oxidation (Fang et al. 2012) and has been previously identified in $\mathrm{PM}_{2.5}$ samples collected 291 from isoprene rich-regions (Surratt et al. 2008). The fragmentation pattern in Figure S4b is 292 consistent with a mixture of isomeric glyceraldehyde sulfate esters. The product ion at $\mathrm{m} / \mathrm{z}$ $293137\left(\mathrm{C}_{2} \mathrm{HO}_{5} \mathrm{~S}^{-}\right)$, can be rationalized as the sulfate ester of hydroxy ketene. In the absence of 
$294 \mathrm{MS}^{2}$ data for both parent ions, however, an alternative explanation for one of the parent ions 295 would be the sulfate ester of dihydroxyacetone (Paulot et al., 2009), which could also give the 296 observed $\mathrm{MS}^{2}$ (Figure S4b).

297 Parent ions at $m / z 179\left(\mathrm{C}_{5} \mathrm{H}_{7} \mathrm{O}_{5} \mathrm{~S}^{-}\right)$and $181\left(\mathrm{C}_{5} \mathrm{H}_{9} \mathrm{O}_{5} \mathrm{~S}^{-}\right)$from isoprene oxidation have not 298 been previously reported. The composition of the parent ion at $\mathrm{m} / \mathrm{z} 179$ indicates retention of 299 the isoprene carbon skeleton. The $\mathrm{MS}^{2}$ spectrum (Figure S4c) is characterized by product ions $300 \mathrm{HSO}_{4}^{-}, \mathrm{HSO}_{3}{ }^{-}$and $\mathrm{C}_{4} \mathrm{H}_{7} \mathrm{O}_{4} \mathrm{~S}^{-}[(\mathrm{M}-\mathrm{CO})]$. The bisulfite product ion is characteristic of a 301 labile proton $\alpha$ to the sulfate substituent, while bisulfate product ion indicates a labile proton accessible 2 or more carbons removed and the loss of $\mathrm{CO}$ indicates a terminal carbonyl group. The isomeric structures 4-oxo-3-(or 2-)methyl-but-2-ene sulfate, sulfate esters of the reported 304 isoprene oxidation products 4-hydroxy-2-(or 3-)-methylbut-2-enal (Baker et al., 2005), are 305 compatible with the $\mathrm{MS}^{2}$ data and hence are proposed as possible structures of the ion at $\mathrm{m} / \mathrm{z}$ 179. The bisulfate product ion and the loss of formaldehyde in $\mathrm{MS}^{2}$ spectrum of the parent ion at $m / z 181$ (Figure S4d) suggest that a labile proton 2 or more carbons removed from the sulfate substituent and a terminal hydroxymethyl group are structural features. Sulfate esters of the known 1,4-, 1,2-, and 3,4-dihydroxy oxidation products of isoprene might yield the 310 observed $\mathrm{MS}^{2}$ trace. However, bisulfite is not present in the $\mathrm{MS}^{2}$ spectrum, thus the $O^{2}$-sulfate ester of 1,2-dihydroxy-2-methylbutene best explains the data (Figure S4d) and is suggested as the structure of the parent ion.

Parent ions at $m / z 213$ having the composition $\mathrm{C}_{5} \mathrm{H}_{9} \mathrm{O}_{7} \mathrm{~S}^{-}$have been detected in ambient 314 SOA collected at K-puszta, Hungary (Gómez-González et al., 2008) and in chamber studies 315 of isoprene photooxidation (Surratt et al., 2008). Based on analysis of $\mathrm{MS}^{2}$ and $\mathrm{MS}^{3}$ data, the compounds observed at K-puszta were assigned as sulfate esters of 4,5-dihydroxypentanoic 317 acid from fatty acid oxidation and 2,3-dihydroxypentanoic acid, a photoproduct of plant leaf 318 volatiles (Gómez-González et al., 2008). The isoprene-derived OSs at $\mathrm{m} / z 213$ were not 
assigned structures and no full-scan or $\mathrm{MS}^{2}$ mass spectra were given (Surratt et al., 2008). The

$320 \mathrm{MS}^{2}$ spectrum acquired in this study (Figure S4e) is characterized by product ions at $\mathrm{m} / \mathrm{z} 183$

$321\left(\mathrm{M}-\mathrm{CH}_{2} \mathrm{O}\right), 139\left(\mathrm{M}-\mathrm{C}_{3} \mathrm{H}_{6} \mathrm{O}_{2}\right)$, and 97 (bisulfate), which are not compatible with either of

322 the pentanoic acid derivatives reported by Gómez-González et al. (2008). A product retaining

323 the isoprene carbon skeleton, 3,4-dihydroxy-3-methyl-2-oxobutylsulfate, could be anticipated

324 to lose formaldehyde and hydroxyacetone as neutral fragments (Figure S4e) and this structure

325 is tentatively assigned to the isoprene-derived OS.

Seven parent ions with 6 or more carbons not previously reported from isoprene ozonolysis were observed (Table 2). The products were mainly observed in experiments using acidified $\mathrm{MgSO}_{4}$ seed aerosol (Table 2) and the low intensity of the parent ions precluded acquisition of $\mathrm{MS}^{2}$ data. Formation of oligomers and their OS derivatives in the presence of

$330 \mathrm{MgSO}_{4}$ seed aerosol has been previously reported and potential involvements of $\mathrm{Mg}^{2+}$ have 331 been discussed (Lin et al., 2014); specifically, $\mathrm{MgSO}_{4}$ aerosols do not effloresce at low-RH 332 conditions and instead form gel-like chain structures of contact ion pairs (Chan et al., 2000). 333 We tentatively propose that this phase state (gel-like chain structures) of $\mathrm{MgSO}_{4}$ allows 334 transient moieties to be held in close proximity to each other by coordination to $\mathrm{Mg}^{2+}$ ions in 335 the gel-like aerosol structure. Future work is needed to more fully resolve the effect of $\mathrm{MgSO}_{4}$ 336 seed aerosol. Consistent with previous work (Surratt et al., 2007b), acidity enhanced the 337 formation of all OSs (Figure 2). $215\left(\mathrm{C}_{5} \mathrm{H}_{11} \mathrm{O}_{7} \mathrm{~S}^{-}\right)$, which have been observed during $\mathrm{OH}$ radical-initiated oxidation of isoprene 340 (Surratt et al., 2007a) are also observed in the ozonolysis experiments in the presence of $\mathrm{OH}$ 341 radical scavenger, although the radical scavenger reduces formation of all OSs. The high 342 concentration of diethyl ether used in this study precludes residual $\mathrm{OH}$ radical as an 343 explanation for these products at observed concentrations. Lack of authentic standards 
344 prevents definitive conclusion as to whether the products at $m / z 153,169$ and 213 from

345 photochemical oxidation and ozonolysis of isoprene are identical or are isobars. However, the

346 sulfate ester at $\mathrm{m} / z$ 215, which was generated in high yield in this study, has been confirmed

347 as a sulfate ester of an isoprene-derived 2-methyltetrol diastereomer (2-methylerythritol or 2-

348 methylthreitol) by comparison with an authentic standard mixture, indicating that both

349 hydroxyl radical and ozonolysis may contribute to 2-methyltetrol sulfate derivatives in 350 ambient fine aerosol.

3.2 Formation of 2-Methyltetrols. 2-Methylterols have been identified in SOA from reactive uptake of isoprene epoxydiol (IEPOX) isomers on sulfate seed aerosols (Surratt et al., 2010; Lin et al., 2012). One study has also reported the formation of the 2-methyltetrols from

354 isoprene ozonolysis in the presence of non-acidified sulfate aerosol (Kleindienst et al., 2007).

355 In the current ozonolysis study, large quantities of 2-methyltetrols were identified in SOA.

356 Consistent with previous studies (Surratt et al., 2007b), the yield of 2-methyltetrols is highly

357 dependent on the acidity and composition of the sulfate seed aerosol (Figure 3), with acidified $358 \mathrm{MgSO}_{4}$ giving the highest yield. Kleindienst et al. (2007) attributed the formation of tetrols 359 during ozonolysis to reaction of isoprene with $\mathrm{OH}$ radicals generated during the reaction, 360 estimating that $16 \%$ of the $\mathrm{OH}$ radicals formed reacted with isoprene. Initial concentration of 361 diethyl ether (35-fold higher than isoprene) prevents any reaction of $\mathrm{OH}$ radicals with 362 isoprene. Indeed, $\mathrm{OH}$ radical oxidation of diethyl ether is 46-fold higher than that with 363 isoprene in experimental conditions used in this work (Mellouki et al., 1995; Atkinson et al., 364 2006). The absence of $\mathrm{C}_{5}$-alkene triols, 2-methylglyceric acid and 3-methyltetrahydrofuran365 3,4-diols, established SOA markers of isoprene photooxidation (Surratt et al., 2010; Lin et 366 al., 2012), also argues against the formation of 2-methyltetrols by $\mathrm{OH}$ radical oxidation. 367 These observations along with the high ratio of 2-methyltetrols to IEPOX-derived OSs (Table 3681 and Figure 3), leads to the conclusion that isoprene ozonolysis in the presence of acidified 
sulfate seed aerosol is a hitherto unrecognized source of 2-methyltetrols. Acid-catalyzed

370 heterogeneous reactions with organic peroxides (Inomata et al., 2014) or $\mathrm{H}_{2} \mathrm{O}_{2}$ (Chen et al., 371 2008), likely to be present in acidic SOA as discussed above, is a possible route for formation 372 of the 2-methyltetrols. Aerosol-phase acid-catalyzed oxidation of isoprene to the 2373 methyltetrols has been proposed and demonstrated in the aqueous phase (Claeys et al., 374 2004b).

3.3 Field measurements. 13 of the 16 OSs identified in the chamber ozonolysis experiments (Tables 1 and 2) were detected in the ambient $\mathrm{PM}_{2.5}$ samples from CTR and LRK sites during the 2013 SOAS campaign. As discussed above in the chemical characterization of parent ions, a number of organosulfates that have not been reported as photochemical oxidation products of isoprene are esters of known photochemical products. The significance of this observation with regard to whether these organosulfates are exclusively generated by ozonolysis via as yet unknown pathways or result from esterification of hydroxy substituents in the aerosol phase remains to be determined. Time profiles of OSs for CTR are shown in 383 Figure 4 and for LRK, in Figure S5. The time profiles exclude the product at $\mathrm{m} / z 249$, to 384 which terpene photolysis may contribute substantially, and the OSs reported Table 1 such as 385 2-methyltetrol sulfates $(\mathrm{m} / \mathrm{z} 215)$, to which photochemically generated IEPOX may contribute 386 substantially, but include the OSs in Table 2, which have not been reported in photochemical 387 experiments. The average concentrations of the ambient OSs, excluding OSs as stipulated 388 above, were $18.3 \pm 12.3 \mathrm{ng} \mathrm{m}^{-3}$ at CTR and $21.3 \pm 20.7 \mathrm{ng} \mathrm{m}^{-3}$ at LRK. Time profiles of the 389 sum of all isoprene-derived OSs identified at LRK and CTR are presented in Figures 5 and 390 S6, respectively. The sum of concentrations of OSs we attribute to isoprene ozonolysis during the 2013 SOAS is highly correlated with the sum of all isoprene-derived OSs $\left(r^{2}=0.75\right.$ for 392 CTR and $r^{2}=0.92$ for LRK). On average, OSs derived from isoprene ozonolysis represent $39314 \%$ of the sum of all isoprene-derived OSs quantified at both CTR and LRK. This is likely 
an underestimate due to complete exclusion of $\mathrm{m} / z 249$ and OSs reported Table 1, which

395 could be formed by other chemical processes, such as photooxidation of isoprene. important source of 2-methylterols, correlation of 2-methyltetrols and OSs from isoprene ozonolysis was calculated and is presented in Figure 5 for both sampling sites. At LRK, a moderate correlation $\left(r^{2}=0.40\right)$ suggests a contribution to 2-methyltetrols from isoprene ozonolysis at this site during the 2013 SOAS campaign. Conversely, the weak correlation at

CTR $\left(r^{2}=0.18\right)$ indicates a smaller role of isoprene ozonolysis in the formation of 2methyltetrols at this site.

405

\section{CONCLUSIONS}

In the present study, the impact of acidified sulfate aerosol on SOA composition arising from isoprene ozonolysis was systematically examined in smog chamber studies.

409 Chemical characterization of SOA demonstrated substantial yields of OSs and 2-methylterols

410 from ozonolysis of isoprene in the presence of acidified sulfate seed aerosol. The presence of 411 an $\mathrm{OH}$ radical scavenger in chamber studies resulted in decreased concentrations of products 412 that could be identified, indicating a contribution to oxidation by $\mathrm{OH}$ radicals. Nevertheless, 413 substantial particle-phase concentrations of both OSs and 2-methyltetrols from ozonolysis in 414 the presence of an $\mathrm{OH}$ scavenger suggest that the SOA yields from isoprene ozonolysis may 415 be underestimated by current models. Furthermore, SOA yields from isoprene ozonolysis 416 have hitherto been determined either without seed particles (Sato et al., 2013) or in the 417 presence of non-acidified aerosols (Kleindienst et al., 2007). Further supporting the 418 conclusion that the contribution of ozonolysis to the isoprene-derived SOA budget is likely 
underestimated, OSs identified in our chamber experiments but not previously reported as

420 products of reactive uptake of photochemical isoprene oxidation were quantified in $\mathrm{PM}_{2.5}$

421 samples collected from two rural sites in the southeastern U.S. SOA yields from isoprene

422 ozonolysis have been reported to increase in the presence of acidified sulfate seed aerosol

423 (Jang et al., 2002); however, SOA composition was not characterized and no hypotheses were

424 offered with regard to mechanisms underlying this effect. A substantial yield of 2-

425 methyltetrols in the presence of a large excess of $\mathrm{OH}$ scavenger supports isoprene oxidation

426 by an alternative pathway, such as acid-catalyzed oxidation by organic peroxides in accord

427 with a previous hypothesis (Claeys, 2004b). A potential source of organic peroxides in the

428 aerosol phase is sCI oligomerization and subsequent uptake, recently reported by Inomata et

429 al. (2014). Further investigation is required to understand how acidified sulfate seed aerosols

430 take up organic peroxides from the gas phase and how particle-phase reactions might degrade

431 organic peroxides into low-volatility products (e.g., OSs) in order to develop mechanisms of

432 SOA formation from isoprene ozonolysis in the presence of acidified sulfate aerosol.

434 AUTHOR INFORMATION

435 Corresponding author: Jason D. Surratt

436 Email: surratt@unc.edu

437 Phone: 1-(919)-966-0470

439 ACKNOWLEDGMENTS

440 The authors wish to thank the Camille and Henry Dreyfus Postdoctoral Fellowship Program 441 in Environmental Chemistry for their financial support. This work is also funded in part by 442 the U.S. Environmental Protection Agency (EPA) grant R835404 and the National Science 443 Foundation grant CHE-1404644. The contents of this publication are solely the responsibility 
of the authors and do not necessarily represent the official views of the U.S. EPA. Further, the

445 U.S. EPA does not endorse the purchase of any commercial products or services mentioned in 446 the publication. The authors wish to thank Kasper Kristensen and Marianne Glasius 447 (Department of Chemstry, Aarhus University, Denmark) who synthesized the 3-pinanol-2hydrogen sulfate.

\section{REFERENCES}

451

452

453

454

455

456

457

458

459

460

461

462

463

464

465

466

467

468

469

470

471

472

473

474

475

476

477

478

479

480

481

482

483

484
Atkinson, R.; Aschmann, S.M.; Arey, J.; Shorees, B. Formation of OH radicals in the gas phase reactions of $\mathrm{O}_{3}$ with a series of terpenes. J. Geophys. Res. 1992, 97, 6065-6073.

Atkinson, R. Gas-phase tropospheric chemistry of volatile organic compounds: 1. Alkanes and alkenes. J. Phys. Chem. Ref. Data 1997, 26, 215-290.

Atkinson, R.; Baulch, D.L.; Cox, R.A.; Crowley, J.N.; Hampson, R.F.; Hynes, R.G.; Jenkin, M.E.; Rossi, M.J.; Troe, J. Evaluated kinetic and photochemical data for atmospheric chemistry: Volume II gas phase reactions of organic species. Atmos. Chem. Phys. 2006, 6, 3625-4055.

Baker, J.; Arey, J.; Atkinson, R. Formation and reaction of hydroxycarbonyls from the reaction of $\mathrm{OH}$ radicals with 1,3-butadiene and isoprene. Environ. Sci. Technol. 2005, 39, 4091-4099.

Budisulistiorini, S.H.; Li, X.; Bairai, S.T.; Renfro, J.; Liu, Y.; Liu, Y.J.; McKinney, K.A.; Martin, S.T.; McNeill, V.F.; Pye, H.O.T.; Nenes, A.; Neff, M.E.; Stone, E.A.; Mueller, S.; Knote, C.; Shaw, S.L.; Zhang, Z.; Gold, A.; and Surratt, J.D. Examining the effects of anthropogenic emissions on isoprene-derived secondary organic aerosol formation during the 2013 Southern Oxidant and Aerosol Study (SOAS) at the Look Rock, Tennessee, ground site. Atmos. Chem. Phys. Discuss. 2015, 15, $7365-7417$.

Chan, A.W.H.; Chan, M.N.; Surratt, J.D.; Chhabra, P.S.; Loza, C.L.; Crounse, J.D.; Yee, L.D.; Flagan, R.C.; Wennberg, P.O.; Seinfeld, J.H. Role of aldehyde chemistry and $\mathrm{NO}_{\mathrm{x}}$ concentrations in secondary organic aerosol formation. Atmos. Chem. Phys. 2010, 10, 7169-7188.

Chan, C.K.; Ha, Z.; Choi, M.Y. Study of water activities of aerosols of mixtures of sodium and magnesium salts. Atmos. Environ. 2000, 34, 4795-4803.

Chen, Z.M.; Wang, H.L.; Zhu, L.H.; Wang, C.X.; Jie, C.Y.; Hua, W. Aqueous-phase ozonolysis of methacrolein and methyl vinyl ketone: A potentially important source of atmospheric aqueous oxidants. Atmos. Chem. Phys. 2008, 8, 2255-2265.

Claeys, M.; Graham, B.; Vas, G.; Wang, W.; Vermeylen, R.; Pashynska, V.; Cafmeyer, J.; Guyon, P.; Andreae, M.O.; Artaxo, P.; Maenhaut, W. Formation of secondary organic aerosols through photooxidation of isoprene. Science 2004a, 303, 1173-1176. 
Claeys, M.; Wang, W.; Ion, A.C.; Kourtchev, I.; Gelencsér, A.; Maenhaut, W. Formation of secondary organic aerosols from isoprene and its gas-phase oxidation products through reaction with hydrogen peroxide. Atmos. Environ. 2004b, 38, 4093, 4098.

Czoschke, N.M.; Jang, M.; Kamens, R.M. Effect of acidic seed on biogenic secondary organic aerosol growth. Atmos. Environ. 2003, 37, 4287-4299.

Edney, E.O.; Kleindienst, T.E.; Jaoui, M.; Lewandowski, M.; Offenberg, J.H.; Wang, W.; Claeys, M. Formation of 2-methyl tetrols and 2-methylglyceric acid in secondary organic aerosol from laboratory irradiated isoprene/ $/ \mathrm{NO}_{\mathrm{X}} / \mathrm{SO}_{2} /$ air mixtures and their detection in ambient $\mathrm{PM}_{2.5}$ samples collected in the eastern United States. Atmos. Environ. 2005, 39, 5281-5289.

Fang, W.; Gong, L.; Zhang, Q.; Cao, M.; Li, Y.; Sheng, L. Measurements of secondary organic aerosol formed from $\mathrm{OH}$-initiated photo-oxidation of isoprene using online photoionization aerosol mass spectrometry. Environ. Sci. Technol. 2012, 46, 3898-3904.

Gaston, C.J.; Riedel, T.P.; Zhang, Z.; Gold, A.; Surratt, J.D.; Thornton, J.A. Reactive uptake of an isoprene-derived epoxydiol to submicron aerosol particles. Environ. Sci. Technol. 2014, 48, 1117811186.

Gómez-González, Y.; Surratt, J.D.; Cuyckens, F.; Szmigielski, R.; Vermeylen, R.; Jaoui, M.; Lewandowski, M.; Offenberg, J.H.; Kleindienst, T.E.; Edney, E.O.; Blockhuys, F.; Van Alsenoy, C.; Maenhaut, W.; Claeys, M. Characterization of organosulfates from the photooxidation of isoprene and unsaturated fatty acids in ambient aerosol using liquid chromatography/(-) electrospray ionization mass spectrometry. J. Mass Spect. 2008, 43, 371-382.

Guenther, A.; Karl, T.; Harley, P.; Wiedinmyer, C.; Palmer, P.I.; Geron, C. Estimates of global terrestrial isoprene emissions using MEGAN (Model of Emissions of Gases and Aerosols from Nature). Atmos. Phys. Chem. 2006, 6, 3181-3210.

Hallquist, M.; Wenger, J.C.; Baltensperger, U.; Rudich, Y.; Simpson, D.; Claeys, M.; Dommen, J.; Donahue, N.M.; George, C.; Goldstein, A.H.; Hamilton, J.F.; Herrmann, H.; Hoffmann, T.; Iinuma, Y.; Jang, M.; Jenkin, M.E.; Jimenez, J.L.; Kiendler-Scharr, A.; Maenhaut, W.; McFiggans, G.; Mentel, T.F.; Monod, A.; Prévôt, A.S.H.; Seinfeld, J.H.; Surratt, J.D.; Szmigielski, R.; Wildt, J. The formation, properties and impact of secondary organic aerosol: current and emerging issues. Atmos. Chem. Phys. 2009, 9, 5155-5236.

Hansen, A.M.K.; Kristensen, K.; Nguyen, Q.T.; Zare, A.; Cozzi, F.; Nøjgaard, J.K.; Skov, H.; Brandt, J.; Christensen, J.H.; Ström, J.; Tunved, P.; Krejci, R.; Glasius, M. Organosulfates and organic acids in Arctic aerosols: Speciation, annual variation and concentration levels. Atmos. Chem. Phys. 2014, 14, 7807-7823.

Hasson, A.S.; Ho, A.W.; Kuwata, K.T.; Paulson, S.E. Production of stabilized Criegee intermediates and peroxides in the gas phase ozonolysis of alkenes 2. Asymmetric and biogenic alkenes. J. Geophys. Res. Atmos. 2001, 106, 34143-34153.

Henze, D.K.; Seinfeld, J.H. Global secondary organic aerosol from isoprene oxidation. Geophys. Res. Lett. 2006, 33, L09812 
Iinuma, Y.; Böge, O.; Kahnt, A.; Herrmann, H. Laboratory chamber studies on the formation of organosulfates from reactive uptake of monoterpene oxides. Phys. Chem. Chem. Phys. 2009, 11, 79857997.

Inomata, S.; Sato, K.; Hirokawa, J.; Sakamoto, Y.; Tanimoto, H.; Okumura, M.; Tohno, S.; Imamura, T. Analysis of secondary organic aerosols from ozonolysis of isoprene by proton transfer reaction mass spectrometry. Atmos. Environ. 2014, 97, 397-405.

Jang, M.; Czoschke, N.M.; Lee, S.; Kamens, R.M. Heterogeneous atmospheric aerosol production by acid-catalyzed particle-phase reactions. Science 2002, 298, 814-817.

Kamens, R.M.; Gery, M.W.; Jeffries, H.E.; Jackson, M.; Cole, E.I. Ozone-isoprene reactions: product formation and aerosol potential. Int. J. Chem. Kinet. 1982, 14, 955-975.

Kleindienst, T.E.; Lewandowski, M.; Offenberg, J.H.; Jaoui, M.; Edney, E.O. Ozone-isoprene reaction: Re-examination of the formation of secondary organic aerosol. Geophys. Res. Lett. 2007, 34, L01805.

Kroll, J.H.; Ng, N.L.; Murphy, S.M.; Flagan, R.C.; Seinfeld, J.H. Secondary organic aerosol formation from isoprene photooxidation. Environ. Sci. Technol. 2006, 40, 1869-1877.

Kroll, J.H.; Seinfeld, J.H. Chemistry of secondary organic aerosol: formation and evolution of lowvolatility organics in the atmosphere. Atmos. Environ. 2008, 42, 3593-3624.

Liggio, J.; Li, S.-M. Organosulfate formation during the uptake of pinonaldehyde on acidic sulfate aerosols. Geophys. Res. Lett. 2006, 33, L13808.

Lin, Y.-H.; Zhang, Z.; Docherty, K.S.; Zhang, H.; Budisulistiorini, S.H.; Rubitschun, C.L.; Shaw, S.L.; Knipping, E.M.; Edgerton, E.S.; Kleindienst, T.E.; Gold, A.; Surratt, J.D. Isoprene epoxydiols as precursors to secondary organic aerosol formation: acid-catalyzed reactive uptake studies with authentic compounds. Environ. Sci. Technol. 2012, 46, 250-258.

Lin, Y.-H.; Budisulistiorini, S.H.; Chu, K.; Siejack, R.A.; Zhang, H.; Riva, M.; Zhang, Z.; Gold, A.; Kautzman, K.E.; Surratt, J.D. Light-absorbing oligomer formation in secondary organic aerosol from reactive uptake of isoprene epoxydiols. Environ. Sci. Technol. 2014, 48, 12012-12021.

Mellouki, A.; Teton, S.; Le Bras, G. Kinetics of $\mathrm{OH}$ radical reactions with a series of ethers. Int. J. Chem. Kinet. 1995, 27, 791-805.

Neeb, P.; Kolloff, A.; Koch, S.; Moortgat, G.K. Rate constants for the reactions of methylvinyl ketone, methacrolein, methacrylic acid, and acrylic acid with ozone. Int. J. Chem. Kinet. 1998, 30, 769-776.

Ng, N.L.; Kwan, A.J.; Surratt, J.D.; Chan, A.W.H.; Chhabra, P.S.; Sorooshian, A.; Pye, H.O.T.; Crounse, J.D.; Wennberg, P.O.; Flagan, R.C.; Seinfeld, J.H. Secondary organic aerosol (SOA) formation from reaction of isoprene with nitrate radicals $\left(\mathrm{NO}_{3}\right)$. Atmos. Chem. Phys. 2008, 8, 4117- 
Nguyen, T.B.; Bateman, A.P.; Bones, D.L.; Nizkorodov, S.A.; Laskin, J.; Laskin, A. High-resolution mass spectrometry analysis of secondary organic aerosol generated by ozonolysis of isoprene. Atmos. Environ. 2010, 44, 1032-1042.

Nguyen, T.B.; Roach, P.J.; Laskin, J.; Laskin, A.; Nizkorodov, S.A. Effect of humidity on the composition of isoprene photooxidation secondary organic aerosol. Amos. Chem. Phys. 2011, 11, 6931-6944.

Olson, C.N.; Galloway, M.M.; Yu, G.; Hedman, C.J.; Lockett, M.R.; Yoon, T.; Stone, E.A.; Smith, L.M.; Keutsch, F.N. Hydroxycarboxylic acid-derived organosulfates: Synthesis, stability, and quantification in ambient aerosol. Environ. Sci. Technol. 2011, 45, 6468-6474.

Pandis, S.N.; Paulson, S.E.; Seinfeld, J.H.; Flagan, R.C. Aerosol formation in the photooxidation of isoprene and $\beta$-pinene. Atmos. Environ. Part A 1991, 25, 997-1008.

Paulot, F.; Crounse, J.D.; Kjaergaard, H.G.; Kroll, J.H.; Seinfeld, J.H.; Wennberg, P.O. Isoprene photooxidation: New insights into the production of acids and organic nitrates. Atmos. Chem. Phys. 2009, 9, 1479-1501.

Safi Shalamzari, M.; Ryabtsova, O.; Kahnt, A.; Vermeylen, R.; Hérent, M.-F.; Quetin-Leclercq, J.; Van Der Veken, P.; Maenhaut, W.; Claeys, M. Mass spectrometric characterization of organosulfates related to secondary organic aerosol from isoprene. Rapid Commun. Mass Spectrom. 2013, 27, 784794.

Sato, K.; Inomata, S.; Xing, J.-H.; Imamura, T.; Uchida, R.; Fukuda, S.; Nakagawa, K.; Hirokawa, J.; Okumura, M.; Tohno, S. Effect of $\mathrm{OH}$ radical scavengers on secondary organic aerosol formation from reactions of isoprene with ozone. Atmos. Environ. 2013, 79, 147-154.

Schindelka, J.; Iinuma, Y.; Hoffmann, D.; Herrmann, H. Sulfate radical-initiated formation of isoprene-derived organosulfates in atmospheric aerosols. Faraday Discuss. 2013, 165, 237-259.

Surratt, J.D.; Kroll, J.H.; Kleindienst, T.E.; Edney, E.O.; Claeys, M.; Sorooshian, A.; Ng, N.L.; Offenberg, J.H.; Lewandowski, M.; Jaoui, M.; Flagan, R.C.; Seinfeld, J.H. Evidence for organosulfates in secondary organic aerosol. Environ. Sci. Technol. 2007a, 41, 517-527.

Surratt, J.D.; Lewandowski, M.; Offenberg, J.H.; Jaoui, M.; Kleindienst, T.E.; Edney, E.O.; Seinfeld, J.H. Effect of acidity on secondary organic aerosol formation from isoprene. Environ. Sci. Technol. 2007b, 41, 5363-5369.

Surratt, J.D.; Gómez-González, Y.; Chan, A.W.H.; Vermeylen, R.; Shahgholi, M.; Kleindienst, T.E.; Edney, E.O.; Offenberg, J.H.; Lewandowski, M.; Jaoui, M.; Maenhaut, W.; Claeys, M.; Flagan, R.C.; Seinfeld, J.H. Organosulfate formation in biogenic secondary organic aerosol. J. Phys. Chem. A 2008, $112,8345-8378$.

Surratt, J.D.; Chan, A.W.H.; Eddingsaas, N.C.; Chan, M.; Loza, C.L.; Kwan, A.J.; Hersey, S.P.; Flagan, R.C.; Wennberg, P.O.; Seinfeld, J.H. Reactive intermediates revealed in secondary organic aerosol formation from isoprene. Proc. Natl. Acad. Sci. 2010, 107, 6640-6645. 
627 Wang, W.; Kourtchev, I.; Graham, B.; Cafmeyer, J.; Maenhaut, W.; Claeys, M. Characterization of 628 oxygenated derivatives of isoprene related to 2-methyltetrols in Amazonian aerosols using 629 trimethylsilylation and gas chromatography/ion trap mass spectrometry. Rap. Commun. Mass 630 Spectrom. 2005, 19, 1343-1351.

632 Xu, L.; Guo, H.; Boyd, C.M.; Klein, M.; Bougiatioti, A.; Cerully, K.M.; Hite, J.R.; Isaacman633 VanWertz, G.; Kreisberg, N.M.; Knote, C.; Olson, K.; Koss, A.; Goldstein, A.H.; Hering, S.V.; 634 De Gouw, J.; Baumann, K.; Lee, S.-H.; Nenes, A.; Weber, R.J.; Ng, N.L. Effects of anthropogenic 635 emissions on aerosol formation from isoprene and monoterpenes in the southeastern United States. 636 Proc. Natl. Acad. Sci. USA 2015, 112, 37-42.

Zhang, H.; Worton, D.R.; Lewandowski, M.; Ortega, J.; Rubitschun, C.L.; Park, J.-H.; Kristensen, K.; Campuzano-Jost, P.; Day, D.A.; Jimenez, J.L.; Jaoui, M.; Offenberg, J.H.; Kleindienst, T.E.; Gilman, 640 J.; Kuster, W.C.; De Gouw, J.; Park, C.; Schade, G.W.; Frossard, A.A.; Russell, L.; Kaser, L.; Jud, W.; 641 Hansel, A.; Cappellin, L.; Karl, T.; Glasius, M.; Guenther, A.; Goldstein, A.H.; Seinfeld, J.H.; Gold, 642 A.; Kamens, R.M.; Surratt, J.D. Organosulfates as tracers for secondary organic aerosol (SOA) 643 formation from 2-methyl-3-buten-2-ol (MBO) in the atmosphere. Environ. Sci. Technol. 2012, 46, $6449437-9446$.

645 

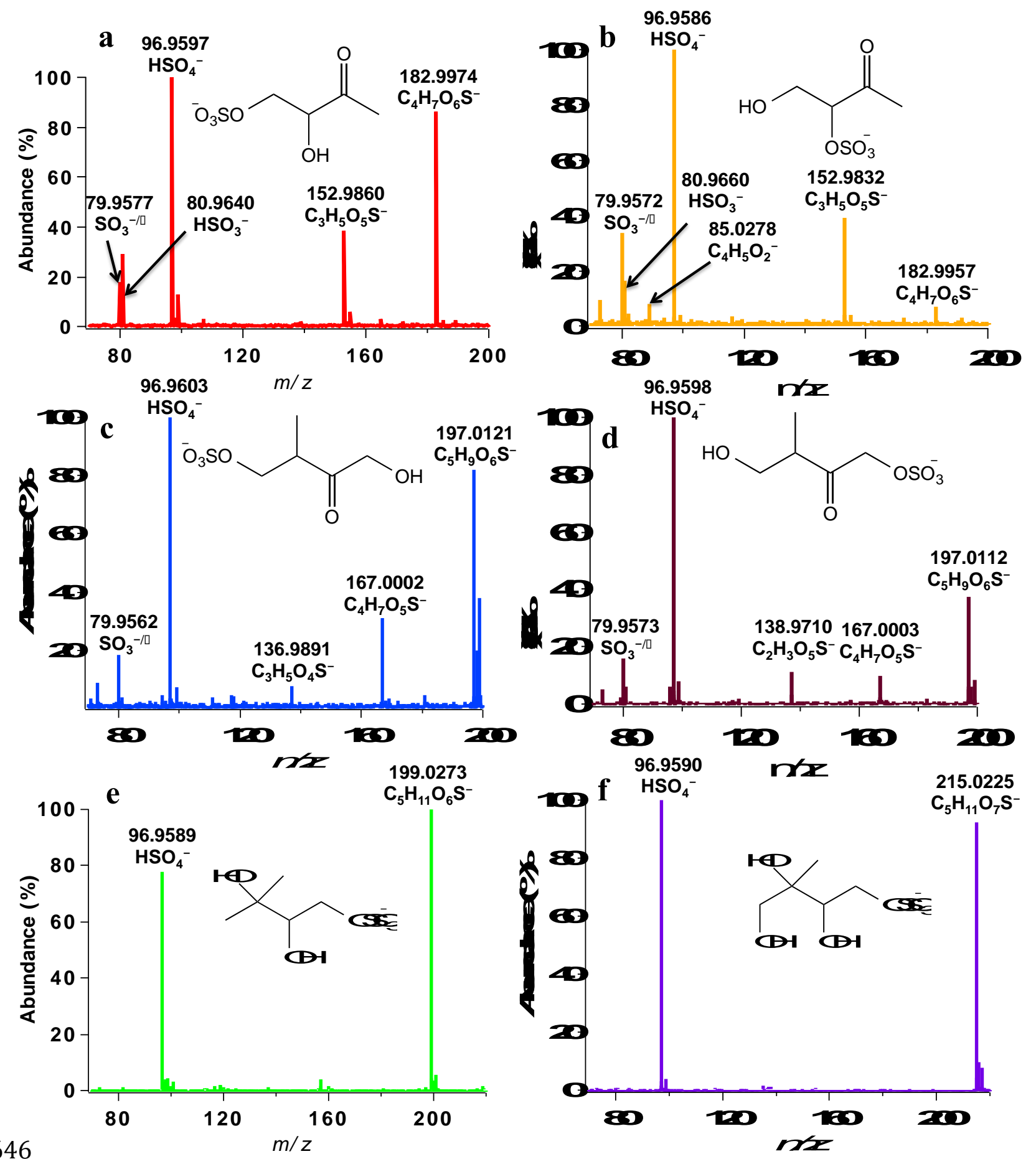

647 Figure 1. $\mathrm{MS}^{2}$ spectra obtained for selected isoprene-derived OSs: (a) early- and (b) late-

648 eluting $m / z 183\left(\mathrm{C}_{4} \mathrm{H}_{7} \mathrm{O}_{6} \mathrm{~S}^{-}\right)$, (c) early- and (d) late-eluting $m / z 197\left(\mathrm{C}_{5} \mathrm{H}_{9} \mathrm{O}_{6} \mathrm{~S}^{-}\right),(\mathrm{e}) \mathrm{m} / z 199$

$649 \quad\left(\mathrm{C}_{5} \mathrm{H}_{11} \mathrm{O}_{6} \mathrm{~S}^{-}\right)$and (f) $m / z 215\left(\mathrm{C}_{5} \mathrm{H}_{11} \mathrm{O}_{7} \mathrm{~S}^{-}\right)$. Proposed structures for the different parent ions are

650 shown as insets on each spectrum.

651 


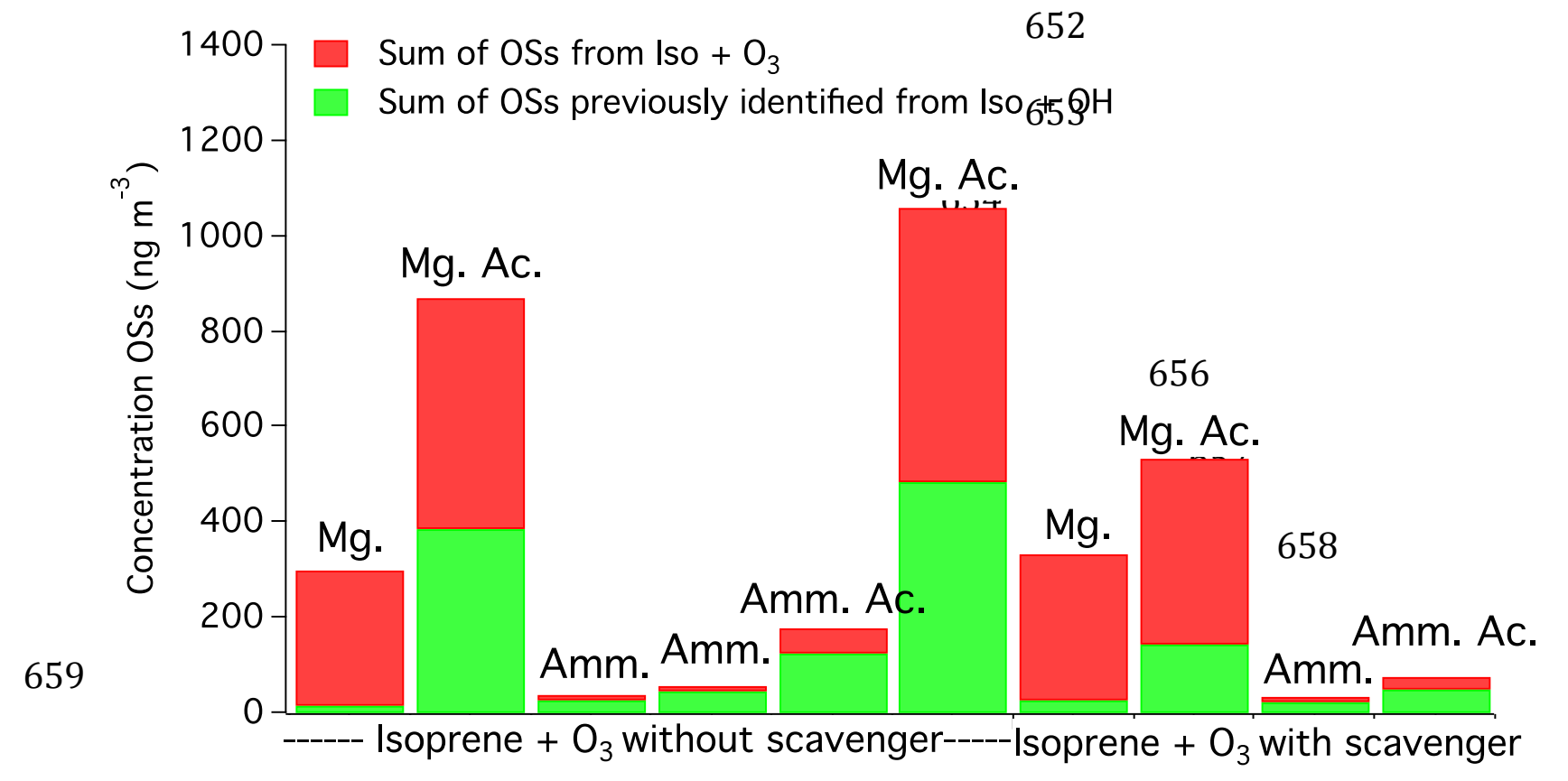

660 Figure 2. Quantification of the all identified OSs produced from the chamber isoprene

661 ozonolysis (experimental conditions are reported in Tables 1 and 2). Presence of OSs in green

662 bars have been previously reported during the photooxidation of isoprene (i.e., OSs reported

663 in Table 1), while OSs in red bars corresponds to compounds identified only during the

664 isoprene ozonolysis experiments (i.e., OSs in Table 2). Mg. and Amm. correspond to

665 magnesium and ammonium sulfate seed aerosol, respectively. Ac. corresponds to acidified

666 sulfate seed aerosol.

667 
668

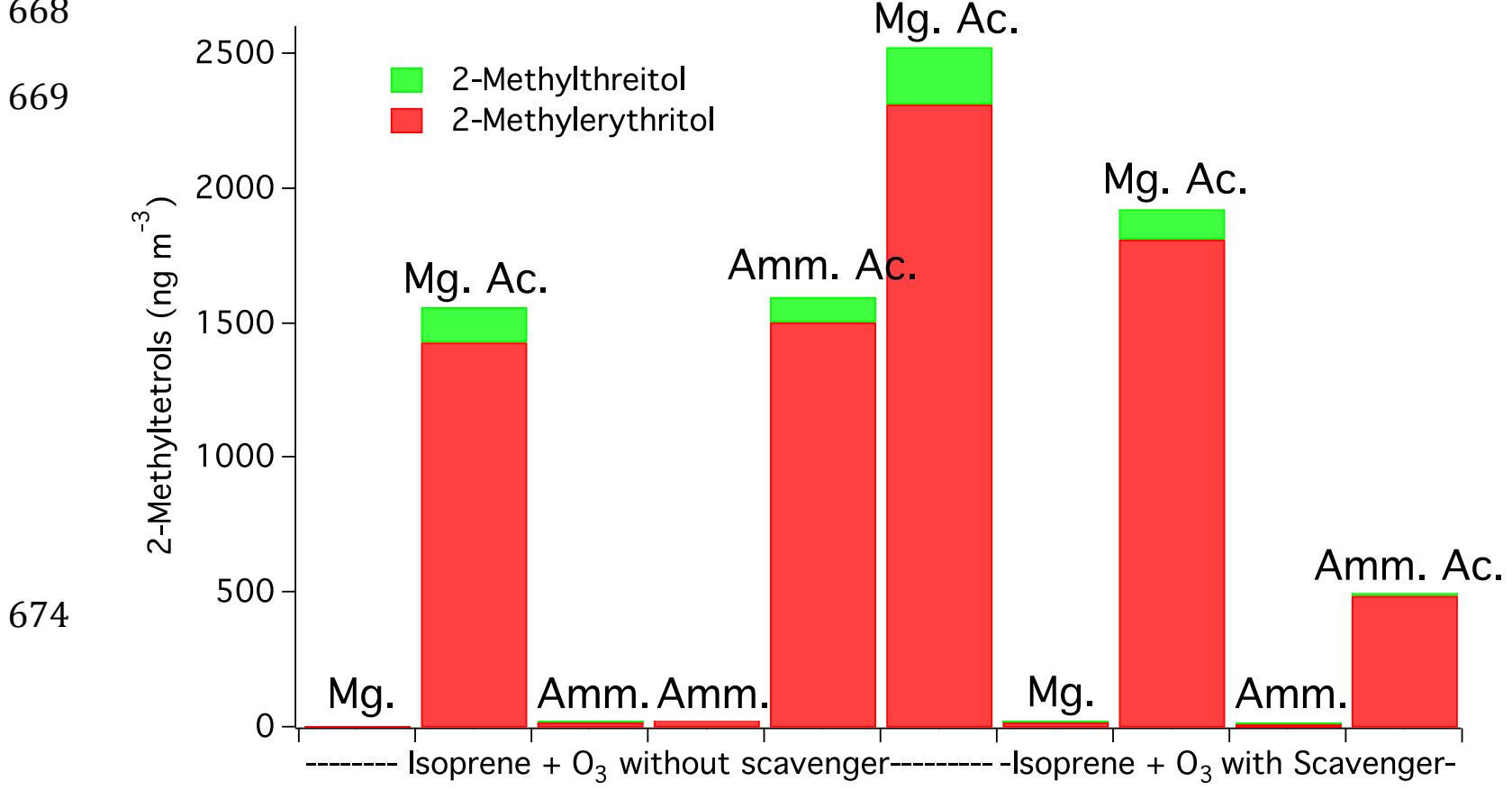

675 Figure 3. Quantification of 2-methyltetrols produced from the chamber isoprene ozonolysis

676 (experimental conditions are reported in Table 1). $\mathrm{Mg}$. and $\mathrm{Amm}$. correspond to magnesium

677 and ammonium sulfate seed aerosol, respectively. Ac. corresponds to acidified sulfate seed 678 aerosol. 


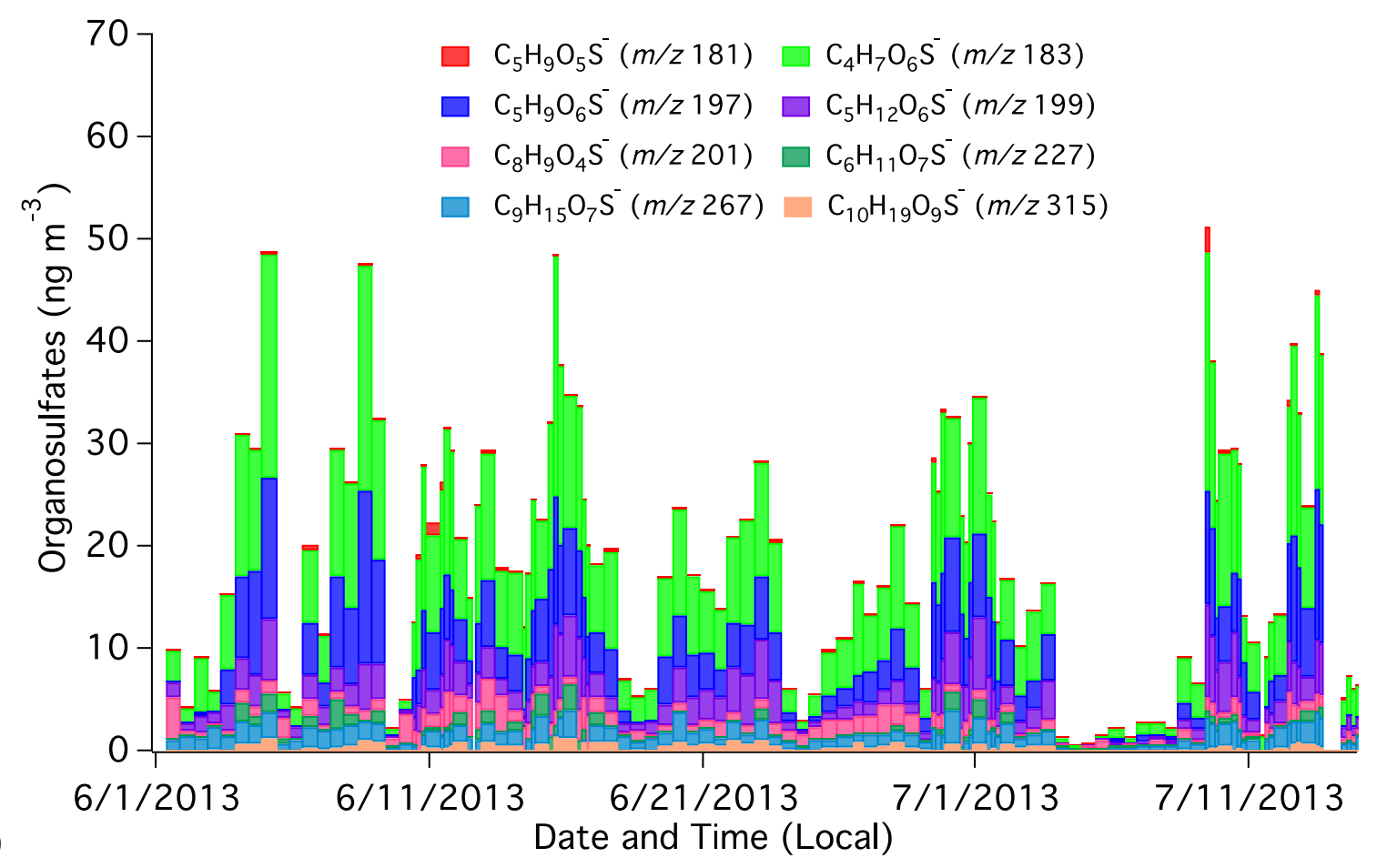

680 Figure 4. Temporal variations of OSs from isoprene ozonolysis-only at the CTR site during 681 the 2013 SOAS campaign.

682 

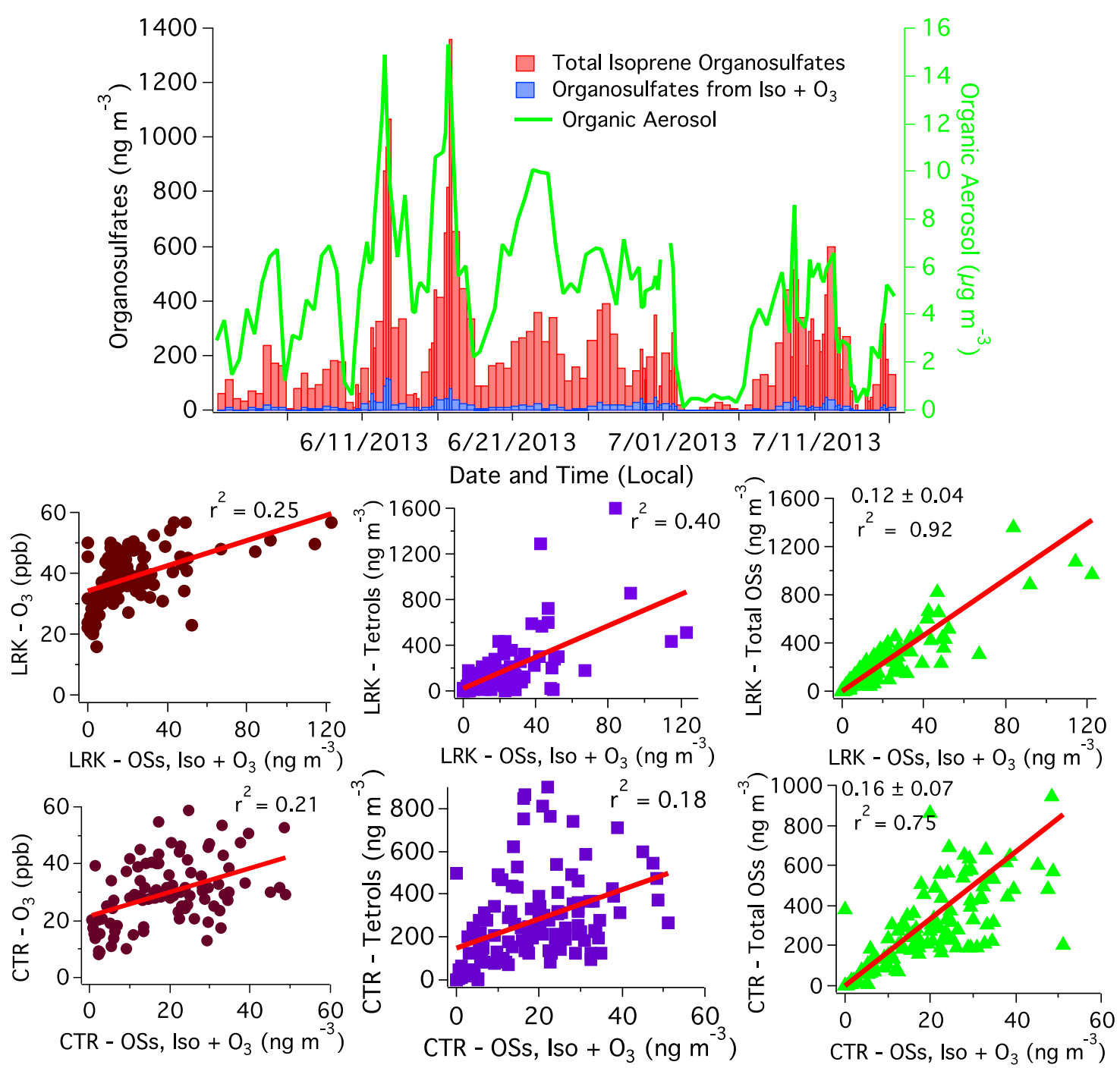

684 Figure 5. Temporal variations of OSs identified in the isoprene ozonolysis-only experiment

685 and the sum of all OSs identified from isoprene oxidation (i.e., by $\mathrm{OH}$ and $\mathrm{O}_{3}$ ) at the LRK site 686 during the 2013 SOAS campaign (upper plot). Organic aerosol concentrations were measured 687 by an Aerodyne Aerosol Chemical Speciation Monitor (ACSM) (Budisulistiorini et al., 2015). 688 and Bottom plots show correlations of the sum of OSs identified from isoprene ozonolysis689 only experiments with ozone (brown markers), 2-methyltetrols (purple markers) and total 690 isoprene OSs (green markers) from both CTR and LRK sites. 
692 Table 1. Summary of experimental conditions and quantification of OSs from isoprene

693 ozonolysis that have previously been identified in isoprene photooxidation experiments

694 (Surratt et al., 2008).

\begin{tabular}{|c|c|c|c|c|c|c|c|c|c|c|c|}
\hline & & \multicolumn{10}{|c|}{ Sulfate seed aerosol } \\
\hline & & Mg. & $\begin{array}{l}\text { Mg. } \\
\text { Ac. }\end{array}$ & Amm. & Amm. & $\begin{array}{c}\text { Amm. } \\
\text { Ac. }\end{array}$ & $\begin{array}{l}\text { Mg. } \\
\text { Ac. }\end{array}$ & Mg. & $\begin{array}{l}\text { Mg. } \\
\text { Ac. }\end{array}$ & Amm. & $\begin{array}{c}\text { Amm. } \\
\text { Ac. }\end{array}$ \\
\hline \multirow{3}{*}{\multicolumn{2}{|c|}{$\begin{array}{c}\text { Scavenger } \\
\text { [Isoprene] (ppb) } \\
{\left[\mathrm{O}_{3}\right](\mathbf{p p b})} \\
\end{array}$}} & \multicolumn{10}{|c|}{---Yes------------------------- } \\
\hline & & 108 & 105 & 104 & 104 & 97 & 96 & 99 & 102 & 100 & 103 \\
\hline & & 118 & 123 & 134 & 134 & 117 & 133 & 118 & 130 & 115 & 126 \\
\hline$[\mathbf{M}-\mathbf{H}]^{-}$ & $(m / z)$ & \multicolumn{10}{|c|}{ Mass concentration $\left(\mathrm{ng} \mathrm{m}^{-3}\right)$} \\
\hline $\mathrm{C}_{3} \mathrm{H}_{5} \mathrm{O}_{5} \mathrm{~S}^{-}$ & $(152.9861)^{\mathrm{a}}$ & 4.1 & 30.4 & 7.5 & 7.5 & 9.8 & 57.5 & 2.8 & 32.3 & 6.7 & 5.0 \\
\hline $\mathrm{C}_{3} \mathrm{H}_{5} \mathrm{O}_{6} \mathrm{~S}^{-}$ & $(168.9820)^{\mathrm{a}}$ & $N . d$. & N.d. & 5.9 & 3.5 & 14.9 & 9.1 & $N . d$. & N.d & 4.8 & 2.1 \\
\hline $\mathrm{C}_{5} \mathrm{H}_{9} \mathrm{O}_{7} \mathrm{~S}^{-}$ & $(213.0071)^{\mathrm{a}}$ & $N . d$. & 35.1 & 2.3 & 7.4 & 7.1 & 37.9 & N.d. & 12.4 & N.d. & N.d. \\
\hline $\mathrm{C}_{5} \mathrm{H}_{11} \mathrm{O}_{7} \mathrm{~S}^{-}$ & $(215.0225)^{\mathrm{a}}$ & 12.8 & 320.7 & 12.7 & 28.8 & 94.5 & 390.5 & 24.1 & 98.9 & 10.7 & 41.0 \\
\hline
\end{tabular}

$695{ }^{a}$ Quantified using synthesized IEPOX-derived OS. Different isomers for one ion have been summed; 696 N.d.: not detected. Mg. and Amm. correspond to magnesium and ammonium sulfate seed aerosol, 697 respectively. Ac. corresponds to acidified sulfate seed aerosol.

698 
699 Table 2 Summary of experimental conditions and quantification of OSs from isoprene 700 ozonolysis not reported as products of isoprene photolysis.

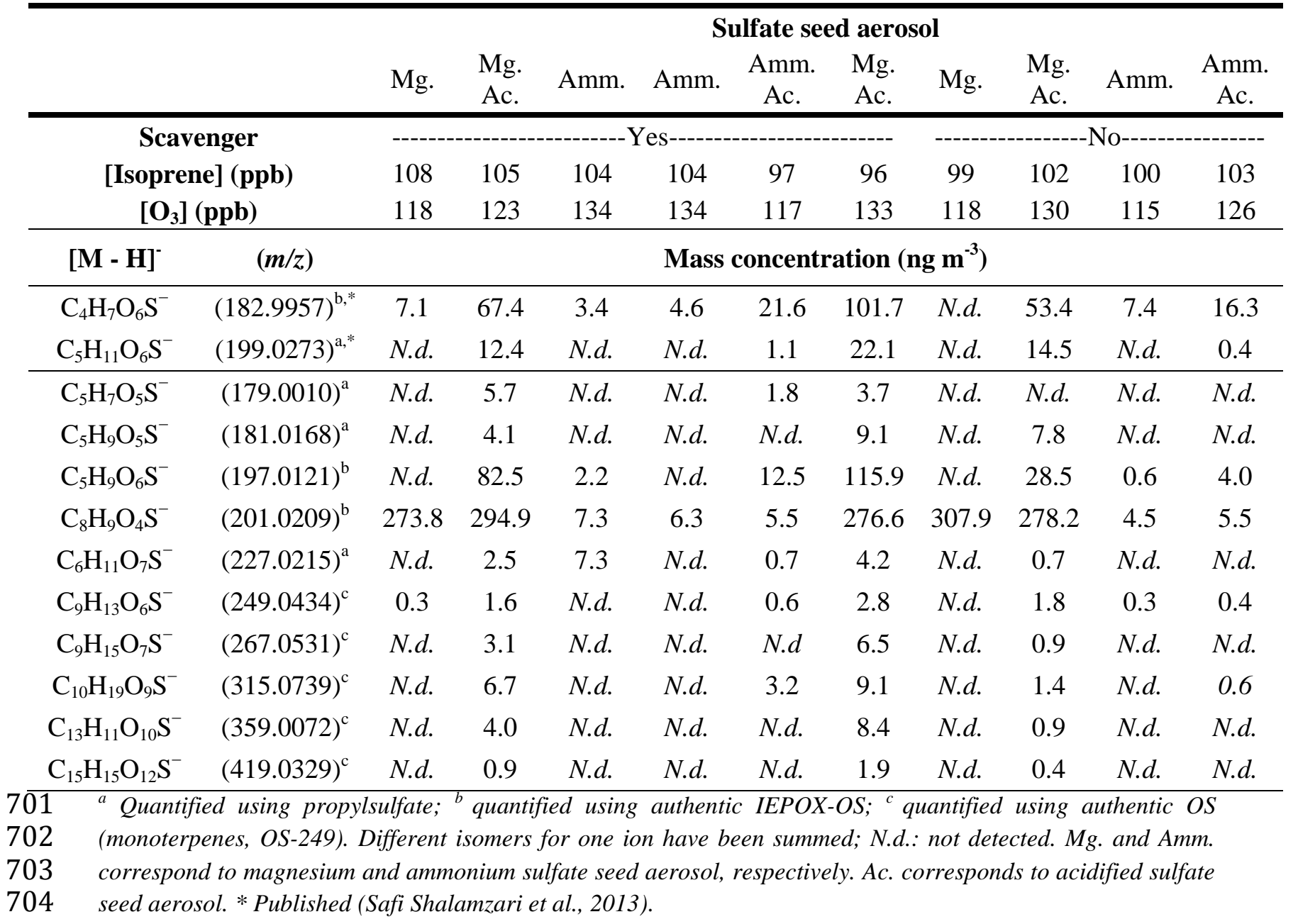

